\title{
An Investigation of the Internet Effects on Business
}

\author{
${ }^{1}$ Farshad Sameni Keivani, ${ }^{2}$ Mohammad Reza Almasi, ${ }^{3}$ Zeinab Khalili Sourkouhi \\ ${ }^{4}$ Sara Makouei, ${ }^{5}$ Morteza Bayat \\ ${ }^{1}$ School of Social Sciences Universiti Sains Malaysia 11800 USM, Pulau Penang, Malaysia \\ ${ }^{2}$ Dept. accounting, Ataturk University, Turkey \\ ${ }^{3}$ Department of Accounting, Roudsar and Amlash Branch, Islamic Azad University, Roudsar, Iran \\ 4, 5 Department of Accounting, Islamic Azad University, Zanjan Branch, Zanjan, Iran
}

\begin{abstract}
In recent years, due to rapid growth of information and communications technology, and most importantly, the expansion and development of internet, the trend of these variations has been accelerated. Electronic is one of these options that many debates are performed concerning the implementation and in particular, its impact on business. In present paper, in addition to defining the electronic insurance, the impact of e-commerce on insurance industry has been discussed. Internet banking has made it easy to carry out the personal or business financial transaction without going to bank and at any suitable time. This facility enables to transfer money to other accounts and checking current balance alongside the status of any financial transaction made in the account. The recent evolution of Information technology in the financial services industry is changing the pace of providing insurance services, not only in India but in the world over. This paper looks at how banks and financial firms can interact with ecommerce. First, banks and financial firms can learn from e-commerce and use the technology and business practice of e-commerce to develop and market their products to the customers. The advent of the internet has revolutionized the way people buy and sell. The internet is characterized by increased access to information. Adaptation of the Internet for commercial purposes in the last decade of the twentieth century has lead to the birth of a new phenomenon: e-commerce.
\end{abstract}

Key words: E-Banking. E- Insurance, E-Commerce, Finance, E-Business

\section{Introduction}

E-Banking is defined as the automated delivery of new and traditional banking products and services directly to customers through electronic, interactive communication channels. E-Banking includes the systems that enable financial institution customers, individuals or corporate to access accounts, transact business, or obtain information on financial products and services through a public or private network, like internet or mobile phone. Internet banking (also referred as e-banking) is changing the banking industry and is having the major effects on banking relationships. Banking is now no longer confined to the branches where one has to approach the branch in person to withdraw cash or deposit a cherub or request a statement of accounts. In true Internet banking, any inquiry or transaction is processed online without any reference to the branch (anywhere banking) at any time. Providing Internet banking is increasingly becoming a "need to have" than a "nice to have" service. The net banking, thus, now is more of a norm rather than an exception in many developed countries due to the fact that it is the cheapest way of providing banking services.

The world witnessed due to rapid development in communication field, emergence of electronic means and their use in all fields, so they became means that cannot be avoided for each individual in the new community, and imposed itself widely. Many contracting procedures are made through computerized electronic systems as a new alternative for contracting through normal cables and correspondences, because of their rapid and accuracy in concluding contracts, and their easiness proofing by electronic methods, such as proof by electronic signature. As a sequence of such advancement in communication technology field, the electronic trade emerged.

E-commerce can be defined as the involvement of electronic and computation devices in providing business services for time saving and cost lowering purposes. It is a new concept in business paradigm which is still at its development stage (Bromideh, 2006) However, over the years, the insurance business has lowered expenses by embracing new technologies in communication and automation. In recent years information technology has lowered the capital costs of insurance through the unbundling of insurance products and through the risk management movement (Stewart et.al. 1998).

In general, e-commerce involves any kind of business or economic activities such as buying, selling, transferring or exchanging products, services or information those are performing through electronic connections. 
Apparently, the company offers diverse utilities, and working as a consultative figure for the banks, monitoring the network, provision of maintenance, and executing all projects that lead to the development of ebanking activities to sustain excellent services delivery.

The above paragraph pervasively constitutes what is meant by e-banking. For many writers and researchers, ebanking is defined within the context of the role it plays as an electronic delivery channel of banking services (Poon, 2008). For the purpose of this research, researchers defined e-banking as all activities that are carried out, processed and delivered through electronic devices in an effort rendering banks services at ease and conveniences.

The insurance industry, on the other hand has been lagging in its adoption of Ecommerce[Garven,1998; Jackson,2003].Although it is recognized that E-insurance has the potential to become a multibillion dollar industry, it is difficult to see how this will occur without some fundamental changes to the way e-insurance is being implemented. The current reality is that few available e-insurance offerings provide any real value and that less than $1 \%$ of all insurance sales are actually being transacted online [Garven, 1998; Pastore, 1999; Jackson, 2003]. This article examines the factors that influence implementation of e-commerce in the insurance industry and suggests some future technological trends that will accelerate the transition to this new era of e-insurance. This article aims at investigating the feasibility of e-insurance services in Asia Insurance Company in Iran [Grossman, McCarthy, Aronson, 2004].

\section{Advantages and Benefits of E- Insurance}

The advantages and benefits of e- insurance are investigable from three perspectives of "insurer", "under contract agencies", and "policyholder":

\section{1- The advantages of insurer}

More speed, in the process of issuing insurance policy and getting damage

- $\quad$ increasing the accuracy in the insurance activities

- $\quad$ upgrading mechanized insurance system, according to the latest hardware and software facilities

- eliminating costly and time-consuming stages, such as issuing letter of introduction, inquiries from centers and...

- $\quad$ reducing the office space of insurance companies through developing virtual space

- Encouraging policyholders to further use of insurance affairs through a perfect informing

- $\quad$ attracting organizations to contracts with insurance

- $\quad$ retaining policyholders and current contract centers

- facilitating the insurance affairs such as documents, reporting, and...

- the possibility of further controlling and managing the affairs of insurance

- the possibility of intelligent performing of some insurance processes such as introducing the policyholder to the medical centers, only by phone or internet and...

- $\quad$ exact analyzing the costs

- integration of mechanized insurance systems in all branches, insurance website and insurance ATM terminals

\section{The advantages of under contract companies}

- the possibility of rapid identifying insurance coverage

- $\quad$ reducing the time repayment to the Center, from insurer

- $\quad$ inhibiting offence and fraud

- the possibility of issuing special insurance policies in Center place without referring to insurer

- $\quad$ rapid identifying the policyholders

- $\quad$ increasing the clients in order to use provided facilities

- rapid identifying letter of introduction

- reducing the administrative costs of the above mentioned Centers in order to communicate with insurer

- increasing the rate of interaction between institutions and insurer affairs

\section{The advantages of insurer}

- increasing the rate of identifying actual insurer

- $\quad$ reducing the frequency of actual presenting in the branches of insurance

- $\quad$ No need to manually completing forms

- the possibility of observing the information of insurance policies related to the policyholder

- $\quad$ No need to provide a letter of introduction

- $\quad$ Ease of paying and receiving related funds

- reducing the time and the cost of using insurance coverage and the resultant satisfaction 
- Increasing familiarization with the insurance affairs by insurer website

- the possibility of taking insurance free consulting through accurate informing of insurers website

- Possibility of direct communicating (virtually) with the managers and administrators in any time and space

- Instant access to statistics and thereby quickly producing reports (Nikoo Fetrat; 2007, 1-3) and (Ahmadi; 2009, 6).

\section{Insurance}

Insurance is an agreement where, for a stipulated payment called the premium, one party (the insurer) agrees to pay to the other (the policyholder or his designated beneficiary) a defined amount (the claim payment or benefit) upon the occurrence of a specific loss. This defined claim payment amount can be a fixed amount or can reimburse all or a part of the loss that occurred. The insurer considers the losses expected for the insurance pool and the potential for variation in order to charge premiums that, in total, will be sufficient to cover all of the projected claim payments for the insurance pool. The premium charged to each of the pool participants is that participant's share of the total premium for the pool. Each premium may be adjusted to reflect special characteristics of the particular policy. Normally, only a small percentage of policyholders suffer losses. Their losses are paid out of the premiums collected from the pool of policyholders. Thus, the entire pool compensates the unfortunate few. Each policyholder exchanges an unknown loss for the payment of a known premium.

\section{Effect of E-Commerce on Insurance Companies}

Insurance companies have regarded the internet mainly as another channel of distribution for their products .Compared to online stock brokerage and online banking, development of the internet in the insurance industry has been somewhat cautious. Websites mainly serve to provide information about the company and its products . Many insurers especially in developing economies have not seized the opportunities created by ecommerce for making all business processes more efficient, beginning with the online sale of policies .But the growing number of those who have embraced the technology is most encouraging[Vress (2002) and Yao (2004)].

\section{E-Insurance}

E-insurance can be broadly defined as the application of Internet and related information technologies (IT) to the production and distribution of insurance services.

In a narrower sense, it can be defined as the provision of an insurance cover whereby an insurance policy is solicited, offered, negotiated and contracted online. While payment, policy delivery and claims processing may all be done online as well, technical and regulatory constraints may not allow these elements to be subjected to full e-commerce application in certain countries (Fisher, 2003). However, insurance legislation worldwide is being continuously modified to accommodate online payment and policy delivery, and outside the discussion of e-e-insurance metrics, these elements should be included in the narrow definition. The anticipated efficiency effect of e-insurance is twofold. First, e-insurance should reduce internal administration and management costs by automating business processes, permitting real-time networking of company departments, and improving management information. Secondly, it should reduce the commissions paid to intermediaries since it can be sold directly to clients. For insurance sold to individuals, agents typically receive a commission of 10 to 15 percent for non-life policy sales and renewals and from 35 to 100 percent for life insurance policies in the first policy year, but much less on renewal (Bender and Marks, 2000; SIGMA, 2001; Fery, 2000).

\section{E-FINANCE SUPPORTING THE EMERGING NEEDS OF E-BUSINESS}

Just as banking and finance have contributed to the development of modern commerce, they can continue the past achievement by contributing to the development of electronic commerce. At the very least, they can make use of the electronic payment media to facilitate transfer of funds associated with electronic commerce. Though the development and use of electronic banking and electronic money are no longer in their early infancy, they still have a long way to go. Another aspect is risk. While providing new opportunities for banks, e-banking activities carry risks which need technological and institutional solutions.

\section{Technological Support to Small Business Clients in E-Commerce}

E-commerce provides a new avenue for a few of the biggest commercial banks with technological capabilities to offer other business firms the technology to conduct business-to-business e-commerce (Wenninger 2000). These big players are assuming the role of automating the entire information flow associated with the procurement and distribution of goods and services among B2B partners5. Being information based and related to financial transactions, these services are seen by banks as an extension of the cash management services they have been providing to large corporations. Banks with technological know-how can offer their 
expertise to assist businesses to participate in e-commerce. In concrete terms, they can help smaller firms set up the infrastructure and payment capabilities to engage in e-commerce. A few banks are offering small businesses in coping with the negotiation of volume discounts from vendors and electronic procurement services (Dalton 1999; Wilder 1999).

\section{References}

[1]. Ganesan R and Vivekanandan K, PhD, (2009), A Secured Hybrid Architecture Model for Internet Banking (e-Banking), Journal of Internet Banking and Commerce, April 2009, vol. 14, no.1

[2]. Marzouq A Alqeed, (2013), Business and its Intelligence level in E- Commerce, International Journal of Business and Social Science Vol. 4 No. 1; January 201338

[3]. Fredrick S. Odoyo and Richard Nyangosi (2011), E-Insurance: An Empirical Study of Perceived Benefits, International Journal of Business and Social Science Vol. 2 No. 21 [Special Issue - November 2011] 166

[4]. Leila Meshkat, (2012), electronic insurance and its application in e-commerce, interdisciplinary journal of contemporary research in business, December 2012 vol 4, no 8

[5]. Anirban Sengupta, Essays in Economics of Electronic Commerce, (2007), Submitted to the Office of Graduate Studies of Texas A\&M University in partial fulfillment of the requirements for the degree of, doctor of philosophy

[6]. Mohamed A. Ismail, (2012), Factors Influencing the Adoption of E-banking in Sudan: Perceptions of Retail Banking Clients, Journal of Internet Banking and Commerce, December 2012, vol. 17, no.3

[7]. Mehrdad Alipour, (2011), Feasibility Study of E-Insurance Services in Iranian Insurance Companies(Asia Insurance Co, International Journal of Business and Social Science Vol. 2 No.10; June 2011

[8]. Sameni Keivani. Farshad et al, 2013, "The Estimation Of The Potential Capacity Of Zakah -A Case Study Of Iran", Journal of Basic and Applied Scientific Research, text road, ISSN 2090-4304

[9]. Sameni Keivani. Farshad et al, 2013, "The Creation Of bankruptcy prediction model with using Ohlson and Shirata models" Journal of Basic and Applied Scientific Research, text road, ISSN 2090-4304

[10]. Sameni Keivani. Farshad et al, 2013, "The Estimation of the Underdevelopment Degree of Different Regions- A Case Study of the Cities of Guilan Province in Iran" World Applied Sciences Journal, 22 (10): 1395-1400, 2013, ISSN 1818-4952

[11]. Sameni Keivani. Farshad et al, "The Historical Lack of Capital Accumulation in Iran's Agricultural Part", 11(5) IOSR Journals of Business and Management (IOSR-JBM) e-ISSN: 2278-487X, p-ISSN: 2319-7668. Volume 10, Issue 4 (May. - Jun. 2013), PP 88-90

[12]. Sameni Keivani. Farshad et al, “Advantages and Barriers of E-Banking in Iran”, Nature and Science Journal 2013;11(5)

[13]. Sameni Keivani. Farshad et al, "The role of Knowledge and confidence in reducing cost of electronic banking customers - a case study of Iran", The 5th International Conference on Financial Criminology (ICFC) 2013 "Global Trends in Financial Crimes in the New Economies",

[14]. Sameni Keivani. Farshad, "Synchronization of Economic Growth and Income Distribution." In 2011 International Conference on Sociality and Economics Development. IPEDR, vol. 10, pp. 7-11.2011.

[15]. Sameni Keivani. Farshad et al, 2011, "Conceptual Approach to E-government, Targets and Barriers Facing its" at the International Conference on Construction and Project Management (ICCPM), September, 16-18, Singapore.

[16]. Sameni Keivani. Farshad et al, 2011, "Conceptual Evaluation E-commerce, Objectives and the Necessary Infrastructure" at the International Conference on Construction and Project Management (ICCPM), September, 16-18, Singapore

[17]. Mikhail Ion Melnik, (2003), Issues in the Economics of E-Commerce, A Dissertation Submitted in Partial Fulfillment of the Requirements for the Degree Of Doctor of Philosophy in Economics In the Andrew Young School of Policy Studies Of Georgia State University

[18]. Lukman Olorogun 1 Ayinde and 2Abdelghani Echchabi, (2012), Perception and Adoption of Islamic Insurance in Malaysia: An Empirical Study, World Applied Sciences Journal 20 (3): 407-415, 2012, ISSN 1818-4952, IDOSI Publications, 2012, DOI: 10.5829/idosi.wasj.2012.20.03.1954

[19]. Fabozzi, F J, Modigliani, F and Ferri, M G (1994) Foundations of financial markets and institutions, New York: Prentice-Hall

[20]. Farhoomand, A and McCauley, M (2001) Trade card: building a global trading electronic payment system Communications of AIS, Volume 7 Article 18

[21]. Wilder, C. (1999) Wells Fargo provides procurement - banks to offer web buying for business customers Information Week Aug 10

[22]. Wind, Y (2001), The challenge of "customerization" in financial services, Communications of the ACM, vol.44, no.6 (June), p. 39 44 